J. Biosoc. Sci., (2019) 51, 18-47, (C) Cambridge University Press, 2018. This is an Open Access article, distributed under the terms of the Creative Commons Attribution licence (http:// creativecommons. org/licenses/by/4.0/), which permits unrestricted re-use, distribution, and reproduction in any medium, provided the original work is properly cited.

doi:10.1017/S0021932017000645 First published online 1 Feb 2018

\title{
GENES AND GINI: WHAT INEQUALITY MEANS FOR HERITABILITY
}

\author{
FATOS SELITA*11 AND YULIA KOVAS*广 \\ *Department of Psychology, Tomsk State University, Tomsk, Russia and \\ $\dagger$ Department of Psychology, Goldsmiths, University of London, London, UK
}

\begin{abstract}
Summary. Research has established that genetic differences among people explain a greater or smaller proportion of the variation in life outcomes in different environmental conditions. This review evaluates the results of recent educationally relevant behavioural genetic studies and meta-analyses in the context of recent trends in income and wealth distribution. The pattern of results suggests that inequality and social policies can have profound effects on the heritability of educational attainment and achievement in a population (Gene-Gini interplay). For example, heritability is generally higher at greater equality levels, suggesting that inequality stifles the expression of educationally relevant genetic propensities. The review concludes with a discussion of the mechanisms of Gene-Gini interplay and what the findings mean for efforts to optimize education for all people.
\end{abstract}

\section{Introduction}

Individual differences in education, health and psychological well-being are a product of complex processes that involve genetic and socio-demographic factors. These factors affect life outcomes by interacting with each other, which complicates the search for specific causal mechanisms underlying variation (Plomin et al., 2016). This review of recent research evaluates whether the strength of genetic contribution to individual differences (heritability) depends on the degree of inequality in resource distribution in a particular population. The first section introduces the commonly used measure of inequality - the Gini Coefficient (Gini). The second section introduces the fundamental and commonly misunderstood concept of heritability. The following two sections briefly overview evidence for effects of inequality (Gini) and genes on education, health and well-being. This is then followed by a review of evidence for the interplay between Gini and heritability (Gene-Gini interplay), focusing on educational outcomes in the context of recent trends in resource distribution in different populations. The Gene-Gini

${ }^{1}$ Corresponding author. Email: ftselita@gmail.com 
interplay refers to two broad phenomena: (1) the strength of the genetic contribution to differences among people in a population depends on environmental conditions (statistical interaction); and (2) environmental conditions may enhance or suppress genetic effects in an individual (causal mechanism). The paper concludes with a discussion of what Gene-Gini interplay means for understanding of the origins of individual differences and for efforts to improve educational outcomes for all people.

\section{The Gini Coefficient and related concepts}

The Gini Coefficient (Gini) was developed in 1912 by Corrado Gini. Gini is the most widely used single measure of inequality, recognized for its attractive theoretical and statistical properties and for being technically sound (World Bank Institute, 2005; De Maio, 2007; Ceriani \& Verme, 2012; Cobham, et al., 2015; Gastwirth, 2016; Davies, 2016). It is used to measure inequality of income or wealth distribution within a certain population or region, or across populations. Gini does not, however, measure the wealth of a population - a wealthy and a poor country can have the same Gini. Wealth of nations is measured by the Gross Domestic Product (GDP) - a monetary measure of the market value of all final goods and services produced in a year (or another period). The GDP per capita is GDP divided by the number of people in the country, which does not reflect differences in the cost of living and the inflation rates of the countries. These are taken into account in the Purchasing Power Parity (PPP) measure. The PPP is an exchange rate at which the currency of one country is converted into that of the second country in order to purchase the same volume of goods and services in both countries (International Monetary Fund; imf.org). The PPP is expressed in international dollars, which have the same purchasing power as US dollars have in the United States. The PPP per capita is GDP converted into international dollars, divided by total population. For some countries, the per capita GDP and PPP are very similar, whereas for others GDP and PPP can differ significantly. Unlike Gini, GDP and PPP measures tell nothing about how resources are distributed within countries.

Gini ranges from 0 to 1 , where 0 means perfect equality (everyone has the same income/wealth) and 1 means absolute inequality (one person gets the whole income/ wealth and the others get nothing). Gini can also be expressed in percentages (Gini Coefficient $\times 100$ ), which is referred to as the Gini Index. However, the two terms (Coefficient and Index) are commonly used interchangeably. Gini is derived from the Lorenz curve, which shows the cumulative proportion of the population, sorted from poorest to richest (or lowest earners to highest earners), on the horizontal axis; and the cumulative proportion of wealth or income on the vertical axis. So, the point $(0.6,0.2)$ would indicate that the bottom $60 \%$ of earners of the selected population earn $20 \%$ of the total income. One way to understand the meaning of Gini is as a percentage scale. So, if income Gini is 0.7 , there is a $70 \%$ inequality and only $30 \%$ equality (equality scoring 30 out of 100). As an example, in the US in 2014, where income Gini was $0.4,0.1 \%$ of the population earned on average US\$6,087,113 each per annum, $1 \%$ of the population earned on average US $\$ 1,260,508$ each per annum and $90 \%$ of the population earned on average US\$33,068 each per annum (Piketty \& Saez, 2003; Saez, 2015).

Gini has some limitations. For example, the total Gini of a society is not equal to the sum of the Gini Coefficients of its subgroups (World Bank Institute, 2005). In addition, 
as Gini depends only on reliable income data, it does not take into account shadow or informal economies. There is also some controversy on whether Gini is more sensitive to changes at the centre of the distribution (Atkinson et al., 2011; Cobham et al., 2015) or to changes in the lower and upper parts of the distribution (Gastwirth, 2016). Despite the relative strengths and weaknesses of different inequality measures, research has shown that they are in high agreement. For example, one study (Kawachi \& Kennedy, 1997) found an average correlation of 0.94 among Gini and five other measures of inequality (the decile ratio; the proportions of total income earned by the bottom $50 \%, 60 \%$ and $70 \%$ of households; the Robin Hood Index; the Atkinson Index; and Theil's entropy measure).

The currently observed range of inequality across the world is very wide, with income Ginis in 2014 varying from 0.25 (Norway) to 0.64 (Comoros); and wealth Ginis varying from 0.42 (Slovakia) to 0.90 (the Russian Federation) (UNDP, 2013; Credit Suisse, 2014). Wealth Ginis are always more extreme than income Ginis. For example, the wealth share of the poorest $50 \%$ of the population is always less than $5 \%$, whereas their income share generally falls in the $20 \%$ to $30 \%$ range (Piketty \& Saez, 2014). In 2014, the wealth and income Ginis were: 0.85 vs 0.4 in the US; 0.73 vs 0.36 in the UK; and 0.56 vs 0.25 in Norway. Income and wealth inequality are reciprocally linked and both lead to consumption inequality (Credit Suisse, 2014; Crawford et al., 2016; OECD, 2017).

It is possible that income and wealth inequality have different impacts on people. In conditions of high average wealth (e.g. high per capita PPP) and low income Gini, a high wealth Gini may not significantly affect people's lives. This is because most people would have good access to quality services and resources. Modern Sweden is a good example of such conditions: the per capita PPP is high (US\$46,445), the income Gini is relatively low (0.27) and the wealth Gini is very high (0.80). In contrast, in conditions of high PPP coupled with high income Gini and wealth Gini, the impact of inequality on people's lives may be very strong, both in terms of lack of resources and negative psychological experiences. The US exemplifies these conditions: the per capita PPP is high $(54,539)$, income Gini is high $(0.41)$ and wealth Gini is very high $(0.86)$. The negative impact of inequality can be further inflated when average wealth is low because people who are disadvantaged by inequality have even fewer resources available to them. For example, in the Russian Federation, the per capita PPP is significantly lower (US $\$ 25,498)$, income Gini is high $(0.42)$ and wealth Gini is very high (0.90) (Credit Suisse, 2014; UNDP, 2014; World Bank, 2017a, b).

When reviewing the literature on inequality, one needs to be aware that studies use different indices and procedures to correct for data limitations. For example, analyses are often based on what is commonly called Earned Income - income received in return for work. Other studies also take into account Capital Income, Capital Gains Income and Business Income, which together account for the greater part of income inequality (Atkinson et al., 2011), but are more difficult measures to ascertain (Alvaredo et al., 2013). As a result, reports often provide somewhat different estimates of Gini. For example, wealth Gini estimated for the same year in the Credit Swiss report was overall higher than that estimated by Allianz (Credit Suisse, 2016; Allianz, 2016). However, despite these differences across studies and reports, the patterns of results are consistent. 


\section{Heritability}

Understanding heritability has become particularly important following recent scientific advancements in genetic science. Although widely used, the concept of heritability is still commonly misunderstood (Kovas \& Malykh, 2016). For example, many hold the mistaken view that heritability relates to a specific person. So, a heritability of $60 \%$ is mistakenly taken to mean that $60 \%$ of an individual's trait (e.g. academic achievement) is determined by the person's genes. In reality, it means that $60 \%$ of the differences in this trait among people within a particular population is explained by their genetic differences (see Kovas \& Malykh, 2016, for a detailed explanation). Heritability of a trait within a population can be estimated (quantified) by using a variety of quantitative genetic methods, such as comparing family members of different genetic relatedness. One of the most common methods is studying a sample of monozygotic (MZ) and dizygotic (DZ) twins drawn from a particular population. Comparing average similarities on a trait of $\mathrm{MZ}$ twins (who are genetically identical) with average similarities of DZ twins (who share on average 50\% of the variable DNA), gives an indication of the relative contribution of genetic and environmental factors to variation in this trait in this particular population. Another quantitative genetic method - the Genomewide Complex Trait Analysis (GCTA) estimates heritability directly by comparing DNA and trait similarities of unrelated individuals (Plomin \& Deary, 2015).

Today we know that variation in any trait stems from multiple, possibly hundreds of DNA variants, and multiple environments, making human traits polyfactorial: polygenic and polyenvironmental. Heritability reflects differences in DNA among all people within a population. Approximately $0.01 \%$ of the human DNA sequence is different among people, with the rest of the sequence being identical for all humans. Although $0.01 \%$ is a small proportion of the genome sequence, it represents millions of DNA variants, each potentially contributing to the observed differences in behaviour. Moreover, recent research suggests that we may be even more different from each other genetically, with each person's DNA containing many rare or completely new (De novo) mutations. It is estimated that the DNA sequence of each person contains an average of 8579 novel genetic variants (Telenti et al., 2016). Importantly, these differences do not refer to race, countries or other population groups, but to differences between any two individuals, even in the same family.

An important aspect of the definition of heritability is that it refers to genetic contribution to differences among people within a particular population at a particular time. This implies that genetic factors can explain a different proportion of individual differences in different populations (even if the overall amount of trait variability is similar). For example, children differ greatly in their academic achievement within all countries. The Programme for International Student Assessment (PISA) study showed that students' performance in mathematics at age 15 varies more within a country than between countries (OECD, 2013). Within a country, the gap between the highest- and the lowest-achieving students was over 300 points, the average score in OECD countries being around 500 points. This difference is enormous, as a performance gap of about 70 score points represents a large difference in skills and knowledge - the equivalent of about 2 years of schooling in a typical OECD country (OECD, 2013). The results also 
suggested that, although most of the variability overlaps across countries, there are also significant differences, especially in proportions of students achieving low and high scores (OECD, 2014).

Between-population variability could arise from differences in allelic frequencies and differences in environmental provisions across populations. Similarly, withinpopulation differences are also a product of both genetic and environmental factors. In fact, genetic variability within a population is so vast that two randomly selected individuals within a population can be more genetically different from each other than two randomly selected individuals from two diverse populations (Jorde \& Wooding, 2004; Witherspoon et al., 2007). Environmental provisions also vary greatly within and between populations. An important question is whether the vast variability in achievement within each population is explained to a different extent by genetic and environmental factors in different populations. For example, if two countries show comparable variances but differ in average performance, variability in one country may be largely due to environmental disparities, whereas in the other it may largely be due to genetic variability (free from environmental limitations). Therefore, interpretations of sources of differences across populations may be complicated by the Gene-Gini interplay. This review evaluates whether environmental provision, and more specifically, inequality, moderates the effects of genes on variation in traits.

\section{Gini's effects on life outcomes}

A large number of studies and reports have concluded that inequality, beyond poverty, has a strong impact on people's lives, including education, health and well-being (e.g. Ryan \& Adams, 1998; Wilkinson \& Pickett, 2006, 2009, 2011; Rowlingson, 2011; Reardon, 2011; Duncan \& Murnane, 2011, 2016; Bischoff \& Reardon, 2014; Carter \& Reardon, 2014; Pickett \& Wilkinson, 2015; County Health Rankings and Roadmaps, 2015). This section provides a brief summary of evidence for the impact of inequality on educational and related outcomes.

The impact of inequality on children's education, health and well-being is partly mediated by parental psychological and physical well-being. Negative psychobiological pathways may be activated by inequality-related feelings of injustice, stress, anxiety about relative social status, loss of social connections and cohesion within communities and insecurity (Kaplan et al., 1988; Singer \& Ryff, 2001; Wilkinson \& Marmot, 2003; Wilkinson \& Picket, 2011; County Health Rankings and Roadmaps, 2015). Inequality may have direct impact on maternal health and stress levels during pregnancy, and on the overall health and mental health of parents. For example, research suggests that the most socially disorganized neighbourhoods, rather than the poorest neighbourhoods, have the highest incidence of schizophrenia (Pinto et al., 2008). Inequality has been linked to increased prevalence of hallucinations and delusional ideation, depression and other mental health problems (Ryan \& Adams, 1998; Wilkinson \& Picket, 2009; Duncan $\&$ Murnane, 2016). These can contribute to parenting problems, such as use of hostile parenting practices (Johnson et al., 2015).

Inequality gets under people's skin by activating many biological processes. Research has shown that relative access to social and material resources is related to differences 
among people in integrity of their distributed brain networks. This link is mediated by multiple processes, including chronic inflammation (e.g. Gianaros et al., 2012). Chronic inflammation arises as a result of many factors, including smoking, adiposity and social integration and support (e.g. Loucks et al., 2006; Ford et al., 2006) - which themselves are associated with socioeconomic status (SES) (e.g. Gianaros et al., 2012). For example, psychosocial stress can directly provoke pro-inflammatory cytokine production (KiecoltGlaser et al., 2010). In addition, exposure to pollution, allergens and lead, as well as noise-related sleep disruptions - more frequently experienced in more disadvantaged neighbourhoods - all trigger long-term biological reactions (Braveman \& Gottlieb, 2014).

Early environment can be linked to later development through epigenetic regulation (e.g. Meaney, 2010). For example, several studies have found that negative life events in early childhood can affect expression of genes involved in immune function (Bick et al., 2012). Other studies found differences in expression of genes involved in inflammation and anti-inflammation between those who grew up in low- and middle-income families (Miller \& Chen, 2007). Socioeconomic disadvantage has been linked to increased expression of inflammatory molecules and proteins, transcriptional changes in genes and intracellular signalling cascades promoting systemic inflammation (Gianoros et al., 2012). The effects can emerge already pre-birth and affect the whole path of development. Mother's stress and anxiety during pregnancy can suppress or enhance genetic expression (e.g. reviewed in Kovas et al., 2016). For example, elevated stress and lack of social support during pregnancy is linked to increased inflammatory activity, affecting immune function, with increased risk of pregnancy and labour complications (Coussons-Read et al., 2007).

Reviews, based on recent large studies, provide evidence for a causal connection between inequality and poor health (Pickett \& Wilkinson, 2015). A recent large study ranked the health of 3061 of 3143 counties/county equivalents in the US (County Health Rankings and Roadmaps, 2015). The results showed that inequality (not just poverty) contributes to increased risk of mortality and poor health. For example, higher ratio between high and low earners within a county was associated with lower life expectancy and higher rates of smoking, cardiovascular disease and obesity. Inequality's effect was present even when communities of similar average income and racial composition were compared (County Health Rankings and Roadmaps, 2015). In a recent book (Ansell, 2017) inequality is described as 'a societal disease' that leads to unequally dispersed biological disease. For example, an average life expectancy gap of 35 years has been estimated between the richest and the most deprived US neighbourhoods (Ansell, 2017). This is consistent with a US study that found substantial correlations (0.50-0.66) between mortality and inequality (on six different measures), even after adjustment for median income and poverty (Kawachi \& Kennedy, 1997). Data from the Office for National Statistics in the UK (www.ons.gov.uk) also show that inequality, beyond poverty, affects life expectancy: the gap in life expectancy at birth increased between the local areas, despite improvements across these areas over the last two decades. Moreover, people in higher socioeconomic positions live longer than those in positions slightly lower than themselves (Marmot et al., 1978; Marmot et al., 1984; Rowlingson, 2011). It has also been shown that rates of infant mortality can be reduced with improvements in Gini, including in wealthy countries (Hales et al., 1999). For example, income Ginis of 0.25 (Sweden, Norway, and Finland), 0.35 (UK), and 0.40 
(US) are associated with mortality rates of 2, 4, and 6 per 1,000, respectively (World Bank, 2015). Taken together, this evidence suggests that, beyond absolute levels of wealth, people's experience of inequality, such as feelings of injustice, unfairness and envy, may lead to elevated stress. In turn, this may trigger cascading negative biological reactions.

The strength of effects of inequality changes as a function of absolute level of wealth. Poverty may override the effect of inequality due to its dramatic limiting effects on development. However, above the poverty line, relative wealth/income may have a stronger effect. For example, data for 21 regions of Taiwan showed that, as living standards rose during the course of rapid economic growth (between 1976 and 1995), income inequality replaced absolute median income as the best predictor of mortality (Chiang, 1999). In developed countries, people on average have better health in countries with lower income Gini, than in those with the highest GDP/PPP (Wilkinson, 1996; Wilkinson \& Pickett, 2006). One large international study, with data from 23 highincome countries, found a strong relationship between income Ginis and the Index of Health and Social Problems endured by populations, including indicators such as life expectancy, mental illness, obesity, educational scores, teenage birth rates, social mobility and education (Wilkinson \& Pickett, 2009). Analysis of data from 50 US states showed very similar results (Kerry et al., 2010).

In developed countries, a clear correlation has also been shown between income inequality and the UNICEF Index of Child Well-Being (Wilkinson \& Picket, 2009). Children in more unequal societies are more likely to be overweight, experience more mental health problems, experience more bullying and victimization and become teenage parents; and less likely to continue education beyond compulsory schooling and have on average lower achievement (Ryan \& Adams, 1998; Pickett \& Wilkinson, 2007; Wilkinson \& Picket, 2009; Reardon, 2011; Duncan \& Murnane, 2011, 2016; Bischoff \& Reardon, 2014; Pickett \& Wilkinson, 2015; UNICEF, 2016).

Several studies suggest that the pattern of increase in inequality and associated educational investment gap corresponds to the increase in educational achievement gap (e.g. Magnuson \& Waldfogel, 2008; Reardon, 2011; Piketty \& Saez, 2003). In the US, the change in inequality has followed a U-shaped trajectory over the last 100 years: high in the beginning of the 20th century, falling between 1929 and the late 1970s, and continuously increasing since then (e.g. 0.40 in 1976 and 0.47 in 2006), with the 2012 Gini being almost as high as in 1929 (Piketty \& Saez, 2003; Saez \& Zucman, 2014; Sommeiller \& Price, 2015; Atkinson et al., 2011).

This increase in overall inequality is accompanied by an increase in the educational investment gap. For example, in 1970, a family with school-age children at the 90th percentile of the income distribution earned five times as much as a family at the 10th percentile; in 2013 the high-income families earned eleven times more than the lowincome ones (Reardon, 2013). Consequently, in 1972 high-income families were spending five times as much per child as low-income families, and in 2007, they were spending nine times more (Kornrich \& Furstenberg, 2013). One study in the US showed an increase in income-based gaps in a range of parenting behaviours over a 25 -year period (beginning in 1979), such as teaching children letters or attending museums. For the most part, these gaps arose from top-income families pulling away from middle- and low-income families (Kalil et al., 2016). 
These increases in income and educational investment gaps have been paralleled by a growing achievement gap. Test scores of children who were adolescents in the late 1960s showed an achievement gap of four-fifths of a standard deviation (about 80 points on a SAT-type test), with children from low-income families lagging behind their better-off peers. Forty years later, this gap was 50\% larger, amounting to nearly 125 SAT-type points. Trends in maths skill gaps were similar (Reardon, 2011; Duncan \& Murnane, 2011). Further research similarly showed that the achievement gap between children from high- and low-income families was roughly $30 \%$ to $40 \%$ larger among children born in 2001 than among those born 25 years earlier (Reardon, 2011; Duncan \& Murnane, 2011). Another US study showed similar results: from 1970 to 2013, the achievement gap between children in families at the 90th percentile and those in families at the 10th percentile of the income distribution grew by $40 \%$ (Reardon, 2013).

Further support for the strong link between the achievement gap and inequality (beyond poverty) is the evidence that the decrease in inequality between black and white children after the 1950s and 1960s (when it was very high in the US) was accompanied by a reduction in the achievement gap between them (Piketty \& Saez, 2003; Magnuson \& Waldfogel, 2008). At the same time, increase in income inequality, which reached a historic high in the 21st century, was accompanied by a significant increase in the achievement gap between children from low- and high-earning families. With these changes, family income became a better predictor of children's success in school than race, with the low-high income achievement gap being twice as large as the black-white achievement gap (Magnuson \& Waldfogel, 2008). Consistent with these findings, a large longitudinal Canadian study (NLSCY) showed that, even once children are out of low income, every incremental increase in household income (in families with low income) is associated with better child development outcomes; and that there is no point above which high income ceases to benefit children's development (Phipps \& Lethbridge, 2008).

Research has also shown that more inequality is associated with less mobility across generations. For example, among OECD countries (in the 1980s), striking associations were found when the most equal (Finland, Sweden, Norway and Denmark) were compared with the least equal (the UK and the US). In Finland, Norway and Denmark, less than one-fifth of economic advantage or disadvantage was passed on from father to son in adulthood. In the UK and the US, roughly $50 \%$ of any advantage or disadvantage was passed on (Corak, 2013).

The PISA study shows an interesting pattern of results on educational equity and achievement. The results showed that approximately $15 \%$ of the variation in student performance in mathematics, reading and science was attributed to differences in students' socioeconomic status. A more socioeconomically advantaged student scored 39 points higher in mathematics (measured by PISA) - the equivalent of nearly one year of schooling - than a less-advantaged student (OECD, 2013). Students attending socioeconomically advantaged schools outscored those in disadvantaged schools by more than 104 points in mathematics, on average across OECD countries. In some countries, small improvements in equity were observed over time (2003-2012): the extent to which students' socioeconomic background predicts their academic performance was reduced; and the gap in performance between advantaged and disadvantaged students narrowed. However, in many countries, educational equity decreased over the same 
period. In some cases, the improved equity was accompanied by increased average performance of a nation. However, in other countries, increase in average performance was observed in the presence of deterioration of equity (OECD, 2013). As discussed in this review, national averages do not reflect experiences of individual students, just as GDP and PPP measures do not reflect socioeconomic circumstances of individuals. Focusing on inequality and heritability measures allows further insights to be gained into the sources of variation in performance within populations.

The trend of growing inequality has been seen in many countries across the world, with 7 out of 10 people living in a country that has seen a rise in inequality in the last 30 years $($ Oxfam, 2017b). Over the last 25 years, the top 1\% ( $\simeq 60$ million people) have gained more income than the bottom $50 \%$ put together; and own more wealth than the rest of the planet ( $\simeq 6$ billion people). Wealth is consolidating in the hands of very few people: in 2010, the 388 richest people had as much wealth as the poorest half of the world (3.6 billion people); in 2017 as few as eight people had as much wealth (Oxfam, 2016, 2017a). In the US, between 2009 and 2012, all income growth happened in the top $1 \%$ of earners in eighteen of the states; and in New York and Connecticut, the top $1 \%$ of earners attained average incomes more than 48 times that of the bottom $99 \%$ (Sommeiller \& Price, 2015). Over 1989 and 2013 the top 10\% owned 87.7\% of household wealth, the top $1 \%$ owned $50.8 \%$ and the top $0.1 \%$ had $20.3 \%$ (Saez \& Zucman, 2014). These trends have happened against a background of increases in absolute wealth, with per capita PPP increasing from US\$37,062 in 1990 to US\$52,549 in 2015 (UNDP, 2016), with the US remaining the richest region in the world (Allianz, 2016). At a global level, it is estimated that over the next 20 years, 500 people will hand over US\$2.1 trillion to their heirs - a sum larger than the GDP of India (Oxfam, 2017a). These severe income inequality trends have been identified by the 2012 survey of the World Economic Forum as the most likely global risk to manifest in the next 10 years (World Economic Forum, 2012).

\section{Genes' effects on life outcomes}

Decades of behavioural genetic research leave us with little doubt that genes have a profound effect on differences among people in all aspects of human functioning (Polderman et al., 2015; Plomin et al., 2016). Recent adequately powered large-scale studies and meta-analyses have confirmed that the heritability of most traits is significant, ranging from moderate to substantial. The most comprehensive metaanalysis to date of the causes of individual differences in human traits examined 17,804 traits from 2748 publications including 14,558,903 twin pairs and concluded that average heritability across all traits is 0.49 (Polderman et al., 2015). The most reliable estimates are available for traits that received much research attention and funding. In the meta-analysis, average (weighted) heritabilities for some of the most studied traits were: 0.54 for blood pressure; 0.50 for conduct disorder; 0.40 for depressive episode; 0.62 for general metabolic function; 0.52 for heart function; 0.50 for immune system function; 0.44 for mental and behavioural disorders due to the use of alcohol; 0.50 for mental and behavioural disorders due to the use of tobacco; 0.44 for other anxiety disorders; and 0.54 for higher-level cognitive functions (Polderman et al., 2015). The Genomewide Complex Trait Analysis (GCTA) studies, which do not rely on data from family 
members, also confirm that common genetic variation among people explains part of the variance in observed traits. The GCTA heritability estimates are usually lower than those from family studies (e.g. half for intelligence). This is because GCTA analysis relies only on genetic effects tagged by common Single Nucleotide Polymorphisms (SNPs) and does not capture rare SNPs or other types of genetic variation, such as Common Number Variants (CNVs) (Plomin \& Deary, 2015).

Research into individual differences in educational traits also clearly suggests a substantial role of genetic factors (e.g. reviewed in Krapohl et al., 2014, 2015). For example, one large-scale UK study demonstrated that state examination performance at age 16 was highly heritable, with genetic factors explaining $62 \%$ of the variation in examination results (Krapohl et al., 2014; Kovas et al., 2015). There are several reasons for why genetic effects on educational achievement are strong. First, genetic effects on achievement have many indirect paths, including through genetic influences on cognition, emotion, personality and motivation (Krapohl et al., 2014). Second, environmental effects, such as SES, are partly confounded by genetic effects (Selzam et al., 2016). Third, initial genetic predispositions get enhanced through the processes of active selection and modification of environments (see below for further explanation of gene-environment correlations). Finally, a standardized educational set-up (as is the case of the UK) may lead to more pronounced genetic effects, as students respond differently to the same circumstances, based on their genetic make-up. This means that equalized circumstances (same resources, standard teacher training, standard curricula, standard class sizes) would reduce the proportion of the variance in achievement explained by environmental disparities, and therefore potentially enhance genetic effects on learning and achievement (Kovas \& Malykh, 2016).

High heritability of education may in turn be reflected in the variance of other traits. For example, a large twin study from the Finnish Twin Cohort found a 0.15 correlation between educational attainment and BMI (Silventoinen et al., 2004). The correlation was mainly explained by common genetic factors (affecting both educational attainment and body weight). This may mean that genetic effects on education contribute to education-associated disparities in BMI in adulthood, although the direction of effects in such associations remains poorly understood.

Molecular genetic methods have begun to identify specific DNA variants that add up to the observed heritability of traits (Plomin \& Deary, 2015). Many recent technological advances enable faster progress in this field. For example, microarray technology enables the genotyping of hundreds of thousands of DNA variants simultaneously. Microarrays can also be used to evaluate epigenetic processes across the genome at the same time. Whole-genome sequencing is becoming increasingly more accessible. It is likely that in the near future most DNA variants that drive the heritability of each trait will be established. Two recent large-scale molecular genetic studies, using DNA and attainment data from 127,000 and 329,000 participants, have already identified a number of DNA variants involved in educational attainment and achievement (Rietveld et al., 2013; Okbay et al., 2016).

Although the effect of each genetic variant is weak, a constellation of a large number of such genetic factors (polygenic score; Plomin \& Deary, 2015) can be used for prediction. One recent study (Selzam et al., 2016) aggregated polymorphisms implicated in educational outcomes by previous studies into a polygenic score and examined 
whether this score predicted variance in educational outcomes at ages 7, 12 and 16 in a sample of $5825 \mathrm{UK}$ individuals. The score predicted up to $9 \%$ of the variation in achievement at age 16 (accounting for $15 \%$ of the heritable variance). Continued progress in genetic research is likely to improve people's ability to predict learning outcomes from genetic data, enabling early diagnosis of learning disabilities. Moreover, this information will be invaluable in further refining of diagnoses and overall better understanding of the multidimensional nature of traits. Better understanding of the genetic architecture of complex traits will lead to new research into specific mechanisms of gene-environment co-action, ultimately contributing to tailoring learning environments to every student's individual needs.

\section{Gene-Gini interplay: how genetic effects on life outcomes change as a function of equality}

This section examines whether the strength of genetic effects on educational outcomes differ across environmental conditions. As inequality is a major factor in creating differences in environments, the term 'Gene-Gini interplay' is used in this paper to describe the gene-environment processes. Heritability may be affected by different sociocultural indices, including absolute wealth of the population (e.g. poverty-related limitations on development such as lack of nutrition, access to education), distribution of wealth (more or less equal opportunity) and educational policies (e.g. compulsory education, standardized curricula).

A disadvantaged environment may reduce genetic effects because it lacks 'food' (educational opportunity, resources, encouragement, choice of activities) for children's genetic 'appetite' for learning. In other words, genetically influenced potentials for adaptive functioning may express more in enriched environments (see Tucker-Drob \& Bates, 2016, for more detail on the Scarr-Rowe Hypothesis of Gene by SES interaction). Equal provision of quality education may buffer the effects of some of the negative environments and also enable evocative and active gene-environment correlation processes. Gene-environment correlation arises as children are exposed to environmental effects in a non-random manner depending on their genotypes (Plomin et al., 1977; Plomin \& Bergeman, 1991). In childhood, correlations are mostly passive and evocative: parents transmit genetic variants to their children and create environments for their children that partly reflect the parents' genetic make-up; parents also modify their own behaviours responding to specific (partly genetically driven) behaviours of their children (e.g. Tucker-Drob \& Harden, 2012; Henry et al., 2016). Active gene-environment correlations emerge when children actively choose their educational environment and activities that correspond with their genetically influenced abilities and interests. In the presence of gene-environment correlation, MZ twins' similarity on a trait remains the same across development, as their genetic predispositions lead to similar environments. In contrast, DZ twins become less similar with age, as they experience progressively more and more different environments.

Limiting environments, such as lack of quality resources, may suppress geneenvironment correlation processes by suppressing expression of the relevant genes. In addition, as discussed above, socioeconomic inequality may relate to educational disparities via inflammatory and other pathways impacting the structural integrity of brain networks (Gianaros et al., 2012). These processes may have cascading implications 
for heritability. Reduced structural integrity of brain networks may lead an individual's developmental trajectory diverging from those enabled by their genetic propensities. For example, genetic predispositions for advanced reading ability may not be expressed if negative neuro-developmental processes affect brain structure and function, suppressing reading ability and motivation. In this case, genetic differences among people would not translate into differences in their reading ability.

Even in the presence of high educational standards and equity, available environments may be inadequate for some students. For example, in the Netherlands, average mathematical performance level in primary education is relatively high, largely because the weakest students are performing better than the weakest students from other countries participating in PISA and other international studies (Schwabe et al., 2017). This is probably due to significant efforts of the Dutch educational system to help weaker students to achieve adequate educational levels (Schwabe et al., 2017). A recent behavioural genetic study suggested that the overall heritability of mathematical ability among Dutch 12-year-olds was high (0.73), suggesting that much of the negative influences of home environments on achievement (particularly at the low end) have been reduced. However, there was an indication that environments explained more variance for gifted students, potentially because inadequate environments suppressed some of the genetically driven giftedness (Schwabe et al., 2017). 'Inadequate' in this case refers to a lack of advanced opportunities that would allow for the expression of the relevant genes.

Good educational provisions may also suppress some of the negative genetic effects. For example, compulsory secondary education requires that students remain at school until 16 or even 18 years of age (e.g. in the UK). This may reduce the effects of genetic propensities on educational attainment (years in education) and associated outcomes. With genetic contributions to dropping out of school minimized, these effects cannot explain variance in whether a person progresses to higher education and for how long.

Because different processes unravel simultaneously and may have opposing effects (enhancing vs suppressing genetic propensities), average heritability differences across populations may be small and difficult to detect. Nevertheless, several specific predictions can be formulated in relation to the effects of wealth (e.g. PPP) and equality (Gini) on heritability of educational traits:

(1) When absolute wealth in a population is low (low PPP), heritability is low, as deprivation limits genetic expression. (2) When absolute wealth is high (high PPP), but resources are distributed unequally (high Gini), the overall heritability is lower than in populations with more equally distributed resources. This is because there are many more inequality-disadvantaged than inequality-advantaged people, and heritability within disadvantaged groups may be lower due to reduced opportunity and lack of gene-environment processes. For some traits, under certain conditions, heritability may also be reduced in advantaged environments, as greater education and opportunity may buffer some negative genetic propensities. (3) When inequality is high (high Gini), irrespective of absolute wealth, heritability is lower. This is because the experience of inequality (especially for those disadvantaged) may be an environmental factor that limits expression of relevant genetic factors. The experience of inequality may activate detrimental for health and education cascading psychological and biological reactions, including anxiety, depression and chronic stress. When environmentally triggered, such effects could contribute to lower heritability of achievement (especially in the 
disadvantaged groups). (4) When absolute wealth is high and more equally distributed (high PPP and low Gini), a very high proportion of the variance is explained by genetic factors.

The best support for the existence and specific mechanisms of the Gene-Gini interplay would come from international studies examining heritability of the same traits in different populations. However, in practice, such research is extremely difficult to conduct: large twin studies are needed, representing comparable populations (e.g. school children of the same age), assessed using the same measures and procedures. The comparisons are further limited because international samples and birth cohorts differ on many parameters, such as educational set-ups, nutrition and other socio-cultural characteristics. This complicates drawing conclusions about the true sources of observed differences in heritability. There is another problem with testing the Gene-Gini interplay hypothesis through international comparisons. To date, most data have been collected in countries that are relatively similar to each other in terms of educational and cultural norms. This reduces the power to detect effects of these norms on heritability. In the most comprehensive meta-analysis to date, twin data were available from only 39 countries, of which most studies were based on US twin samples (34\%). Samples from South America, Africa and Asia were heavily under-represented (5.7\%, combined) (Polderman et al., 2015).

These limitations preclude a robust test of the four predictions. However, available data allow a preliminary examination of the Gene-Gini interplay hypothesis. The following sections review three strands of evidence on whether heritability of educational traits differs: (1) among population subgroups within a country at a particular time (e.g. people of lower and higher socioeconomic status); (2) among birth and age cohorts within a country (e.g. people born before and after social reforms; pre-school and school children); and (3) across countries, at a particular time.

\section{Subgroups within a country at a particular time}

A number of studies have provided evidence for variation in genetic influences on intelligence and educational achievement across families, schools and states within nations, in particular, as a function of socioeconomic status (SES). Several studies have found that genetic factors have greater effects on IQ and education at higher home SES levels (see Tucker-Drob et al., 2013, for a review). In addition, a recent study found that school SES may also moderate genetic influences on verbal intelligence at the individual level (Schwartz, 2015). The study used a sample of over 2000 sibling pairs, drawn from the National Longitudinal Study of Adolescent to Adult Health (AddHealth) in the United States. The school-level SES measure was based on the average of the householdlevel SES measure for each of the students attending each of the 144 schools included in the study. The results indicated that genetic factors have a greater influence on verbal IQ for students who attend schools with higher levels of SES, and shared environmental factors have a greater influence on verbal IQ for students who attend schools with lower levels of SES. However, the differences were significant only at extremely high and low levels of SES (within the top or bottom 10th percentiles).

Several studies, conducted outside the US, have failed to replicate the moderating effect of SES on heritability. For example, a recent study of a representative sample of 1176 Australian adolescent twin pairs found no evidence for higher heritability of intelligence 
among those from higher SES backgrounds (Bates et al., 2016). Mean IQ was modestly higher for higher SES participants, but heritability was equally high (0.83) at all levels of SES. It is possible that equity of school provision in today's Australia buffers against wealth and income inequality and allows for greater expression of genetic potential.

Similarly, a study conducted in the UK failed to replicate the moderating effect of SES on heritability, despite being powered to detect even modest effects (Hanscombe et al., 2012). The study was based on the data from 8716 twin pairs from the Twins Early Development Study (TEDS), born between 1994 and 1996. Data on intelligence were collected when the children were $2,3,4,7,9,10,12$ and 14 years of age. The genetic effects on intelligence were similar in low- and high-SES families, again suggesting that relatively uniform school provision buffers against wealth and income inequality to some extent. The variance in intelligence was greater in low-SES families, which was explained by moderation of the environmental effect - an environment-environment interaction. Children's shared environments (rather than individual specific experiences) appeared to explain the greater variation in intelligence in lower SES (Hanscombe et al., 2012).

Yet another study, using the UK TEDS sample (Asbury et al., 2005), found that heritability was greater (not lower) for children from families with a disadvantaged home atmosphere. The study examined the associations of verbal and non-verbal abilities with ten measured environments, using a sample of 4-year-old same-sex twins ( $N=4446$ children). The results showed higher heritability of verbal ability among children whose home was more chaotic, and whose parents engaged in less communication with their children. Therefore, heritability can be greater in high-risk environments, with genes providing a diathesis and environment acting as a trigger for its effect (diathesis-stress model). The lower heritability in a better home environment might mean that such an environment suppresses some of the negative genetic effects on early verbal development.

The inconsistent pattern of results across studies indicates that the degree and direction of the gene by SES interaction differ across populations. A recent metaanalysis further supported this explanation in relation to intelligence and academic achievement (Tucker-Drob \& Bates, 2016). The study examined differences in heritability between higher and lower SES groups within the US, Australia, Germany, the Netherlands, Sweden and the UK. The meta-analytic dataset consisted of 43 effect sizes from a total of 24,926 pairs of twins and siblings with varying degree of genetic relatedness from fourteen independent studies. Data were relatively evenly split across the US and non-US samples: US (eighteen effect sizes, eight studies, 10,831 twin or sibling pairs); and Western Europe and Australia (25 effect sizes, six studies, 14,095 twin or sibling pairs). Family SES during childhood was based on parental education, family income or parental job prestige. Sophisticated methods for estimating effects were used, accounting for the publication bias and between-study heterogeneity.

The results indicated gene by SES effects in the US: genetic variance in intelligence was significantly lower (0.24) at 2 standard deviations (SD) below the mean SES than at 2 SD above the mean SES (0.61). In contrast, zero, or even small reversed effects were found in studies from Western Europe and Australia. In an unconditional meta-analytic model, the meta-analytic mean for the heritability by SES interaction was non-significant. When a dummy-coded nation variable $(0=$ non-US, $1=\mathrm{US})$ was added to the meta-regression model, there was a significant difference between heritability by SES effect sizes from the US compared with those from Western 
Europe and Australia. The SES by heritability interaction found in the US samples was not a product of methodological differences between the studies, such as childhood age or how SES, achievement and intelligence were measured. Previous research also suggests that the observed pattern in the US cannot be explained by racial differences within the population. For example, heritability by SES effects were still present in a nationally representative sample of American children when race and its effects on genetic and environmental components were controlled (Tucker-Drob et al., 2011).

The finding of differences in the strength of heritability between lower and higher SES in the US, but not in other countries, may be explained by differences in resource distribution across nations. The Western Europe countries and Australia have more uniform access to high-quality education, health care, overall social welfare and greater social mobility than the US (Tucker-Drob \& Bates, 2016). As described above, the US has a higher wealth and income Gini, and a greater proportion of people living below the line of poverty than Western Europe countries and Australia (Social Policy Research Centre, 2016; OECD, 2017).

\section{Birth cohorts within and across countries}

Another test of Gene-Gini interplay is examining whether changes in social provision and equality within a country are accompanied by changes in heritability. Several studies have provided relevant data for educational attainment (years in education/degree achieved). Academic attainment is sensitive to many socio-cultural trends, including general access to education, whether and how much education is compulsory and whether it is equally available to males and females. Previous research has found that overall heritability of educational attainment (level of education achieved) is somewhat lower than that of educational achievement (success of mastering the curriculum). This should particularly be the case in populations where there are environmental restrictions on access to education. A recent meta-analysis (Branigan et al., 2013) examined available data (twin correlations) from ten countries to estimate heritability of educational attainment in 34 subgroups, split by sex, birth cohort and nationality. The grand mean heritability of educational attainment for the ten countries in the meta-analysis was 0.40 , consistent with other research. For example, in the UK TEDS study, heritability was 0.44 for the decision to stay in education for an additional 2 years beyond the compulsory requirement (Rimfeld et al., 2016). In contrast, the choice of specific subjects (e.g. mathematics vs history) to study for these additional years was more heritable (0.5-0.8), and the heritability of grades (success) in different subjects at the end of the 2 years was on average 0.59 . These results suggest that opportunity/decision to continue education is particularly affected by family and other socio-cultural factors, such as availability of educational resources (e.g. extra tutoring in preparation for state exams) or affordability of higher education. In contrast, genetic factors explain more variance in educational success and choice of subjects, especially in uniform educational systems like that of the modern UK.

The meta-analysis of heritability of educational attainment in different birth cohorts provided further evidence for Gene-Gini interplay (Branigan et al., 2013). Overall, genetic variation explained 8 percentage points more of the variance in attainment for those born after 1950 than for those born earlier. The authors suggested that the lower heritability in earlier cohorts reflects greater dependency of educational attainment on 
social class for respondents in the earlier cohorts. The trend of increased heritability in later cohorts was also observed for individual countries in the meta-analysis (although most differences did not reach statistical significance). For example, in Norway, for which three cohorts were available, heritability of educational attainment was: 0.18 (males) and 0.28 (females) for those born in 1915-1939; 0.68 (males) and 0.34 (females) for those born in 1940-1949; and 0.76 (males) and 0.46 (females) for those born in 19501960. This increase in heritability happened along with the overall decrease in income Gini for Norway (Chartbook of Economic Inequality, 2017); increased access to education aided by government-sponsored student loans and other social changes; and a dramatic growth in educational attainment for Norwegian adults (from 5.92 years in 1960 to 11.86 years by 2000; Tucker-Drob et al., 2013).

Similar trends were observed in the three Australian samples in the meta-analysis. Heritability was: 0.34 (males) and 0.44 (females) for those born in 1893-1950; 0.54 (males) and 0.52 (females) for those born in 1951-1965; and 0.28 (males) and 0.77 (females) for those born in 1964-1971. Although most differences were not statistically significant, the results overall are consistent with increase in heritability in educational attainment, with shifts towards universal access to education and other positive social changes. The income Gini in Australia has decreased from 1950, remaining moderate and relatively stable in the last three decades (World Bank, 2017a; Chartbook of Economic Inequality, 2017).

Interestingly, the results for the US cohorts in the meta-analysis did not follow the trend of increased heritability in later cohorts. For the six available US samples, heritability was: 0.44 (males) for those born in 1917-1927; 0.46 (males)/0.3 (females) for those born in 19361955; 0.44 (males) for those born in 1939-1957; 0.29 (males) and 0.26 (females) for those born in 1921-1969; 0.34 (males) and 0.36 (females) for those born in 1911-1985; and 0.27 (males) and 0 (females) for those born in 1976-1984. These results suggest a trend towards a decrease in heritability in more recent cohorts. This trend is mirrored by the increase of Gini in the US, starting in the late 1970s until today, as described in the Gini section above.

One country (not included in the meta-analysis), Russia, has gone through similar decreases in equality of wealth and income distribution as the US. In the 1990s Russia underwent an enormous change in socioeconomic structure - a transition from more equally distributed resources (in the Soviet Union) to a much greater inequality, with wealth and income inequality almost doubling during the transition (Galbraith et al., 2004). For example, income Gini for Russia increased from 0.24 (1988) to 0.48 (1993) and has remained high (and similar to that of the US) since then (e.g. 0.41 in 2005; 0.42 in 2012) (World Bank, 2017a). The absolute wealth in Russia dropped from a PPP of US $\$ 20,639$ in 1990 to that of US\$12,813 in 1995 , then rose again to US\$23,895 in 2015 (UNDP, 2016). Therefore, the mid-1990s was a particularly problematic period, when inequality emerged across all areas of life, including in educational provision, accompanied by worsening of funding and educational conditions in schools (Voronin et al., 2016). Prior to the 1990s, the school system was highly standardized, with all children receiving free school meals, the same free textbooks and a uniform curriculum. Today, although the curriculum remains relatively standardized, there is a greater choice of programmes available to schools; private schools are available at high cost; and private tuition is widely used by those who can afford it for their children. According to PISA, the average academic performance in mathematics (at age 15) improved in Russia 
between 2003 and 2012. However, the overall educational equity deteriorated, reflected in the increased percentage of variation in mathematics performance explained by the PISA index of economic, social and cultural status (OECD, 2013).

Although no large-scale twin studies have been conducted in Russia, the available data from smaller studies suggest a similar pattern to that observed in the US. For example, in a study of 160 young twins (16-28 years old) who were school children in the 1980s, substantial heritability was found for verbal, performance and full-scale IQ, measured with the Wechsler Adult Intelligence Scale (WAIS): 0.86, 0.89 and 0.89, respectively (Malykh et al., 2005). Another small study from the same period assessed intelligence in 123 pairs of 16-year-old Russian twins (Grigorenko et al., 1992) and found overall moderate heritability: 0.49 for Performance IQ and 0.29 for Verbal IQ, assessed by WAIS; and 0.97 for mathematics, 0.57 for spatial and 0.17 for verbal subtests of the Amthauer Intellectual Test. The two studies differed in age of participants, which might explain the lower heritability in the younger sample (Grigorenko et al., 1992). The overall moderate to high heritability found in both studies could reflect the social homogeneity in Russian society at the time of assessment, eliminating much of the environmental variance between families.

In contrast, low heritability was found after the reforms of the 1990s. One study of 580 twins in Russia examined the heritability of non-verbal ability (measured by Standard Raven's Progressive Matrices) in adolescents aged 10-14 years born in the mid-1990s (Malykh et al., 2016). Both MZ and DZ twins were highly similar, suggesting that individual differences in non-verbal ability were explained almost entirely by family environment (65\%) and person-specific environment (29\%), with minimal genetic effects $(6 \%)$. Another study also found low heritability in the data collected in 1994-1997 and 1997-2000 (Voronin et al., 2016). Average heritability was 0.27 (with six out of eleven subtests showing non-significant genetic influences) for intelligence, measured by the Wechsler Intelligence Scale for Children (WISC-III) in a sample of 201 twin pairs of 13-year-old twins. The same study showed average heritability of 0.27 (with eight out of eleven subtests showing non-significant genetic influences) for intelligence measured with the WAIS-III in 148 pairs of 16-year-old twins. Overall, heritability of intelligence found in the two studies was lower than that found in earlier cohorts and in other countries. For example, heritability of non-verbal intelligence in adolescents born in the mid-1990s in the UK was moderate (Hanscombe et al., 2012). Explanations for the low heritability, suggested by the authors, included assortative mating (which masks heritability through making DZ twins more similar to each other) and features of parenting, such as parental involvement in children's education. Consistent with Gene-Gini interplay, the authors also discussed as a potential explanation the lower socioeconomic status of families and associated decrease in gene-environment processes, as well as inequality-related increase in environmental variance (Malykh et al., 2016; Voronin et al., 2016).

Spain is another country that has provided an opportunity to test the interaction between educational equality and heritability of educational attainment. In 1970 a specific educational policy was introduced in Spain that decreased environmental variance in the population and increased equality in educational opportunities (ColodroConde et al., 2015). The 1970 General Law on Education marked, among other changes, an extension of mandatory education to 14 years of age, and the introduction of the same curricula for boys and girls (Colodro-Conde et al., 2015). A recent study used a 
population-based sample of 1271 pairs of adult twins to analyse the effect of this specific educational policy on heritability. The unique aspect of the study is that it used a very specific educationally relevant cut-off (introduction of the reform) for comparison between the cohorts, rather than less-specific cut-offs, such as pre- vs post-war or collapse of the political system.

Participants were over 40 when they were interviewed, and for the analysis were divided into two groups: the pre-reform cohort, consisting of twins born before 1961 (65.4\%), and the post-reform cohort, consisting of twins born in 1961 and after (34.6\%). The study provided further support for greater heritability of educational attainment in conditions of greater equality in educational opportunities. For men, heritability increased from 0.44 in the pre-reform cohort to 0.67 in the post-reform cohort. Heritability remained in the same range for women ( $0.40 \mathrm{vs} 0.34 \%)$. The increase in heritability (for men) was probably due to the implementation of more egalitarian educational policies: as the influence of family socioeconomic status decreased, genetic differences between individuals made a greater impact on the variation of educational attainment.

There is no definitive explanation for why heritability did not increase in the postreform cohort of women. The total variance in educational attainment was reduced in the post-reform cohort, with both men and women born after 1960 more likely to have completed medium and high education levels than those born pre-reforms. However, on average, fewer women achieved a high educational level regardless of cohort. In men, the reduction in individual differences was almost exclusively accounted for by shared environmental factors. In women, the reduction in individual differences occurred due to reduction of both shared environmental and genetic variance. This could be because genetic factors, which increase the risk of girls of dropping out of school early, were now suppressed by compulsory education. In other words, environmental constraints may have depressed 'negative' heritability by compelling girls to attain higher levels than they otherwise would (Tucker-Drob et al., 2013). The absence of an increase in heritability for women is consistent with studies in other countries that found overall lower heritability of educational attainment and achievement for women (e.g. Branigan et al., 2013). It is possible that socio-educational changes unravel more slowly for females, with benefits of reforms reaching women later than men. Consistent with this explanation, a number of more recent studies reported minor or no differences between men and women in the weight of genetic and environmental factors on variation in academic achievement (e.g. Shakeshaft et al., 2013). This could be the result of the substantial recent efforts to provide equal gender opportunities and the overall positive change in attitudes towards gender equality in many countries.

\section{Age cohorts within and across countries}

Support for the Gene-Gini interplay also comes from findings of increased heritability with age for some traits. For example, the pattern of results that emerged from cross-cultural longitudinal research on literacy is consistent with the hypothesis of greater equality leading to greater heritability (e.g. Kovas et al., 2005; Samuelsson et al., 2008; Hayiou-Thomas, 2008). The research demonstrated that heritability of reading skills varies as a function of students' age and educational set-up, including the extent to which the formal education system is able to buffer the effects of socioeconomic inequality. One study (Samuelsson et al., 2008) assessed the literacy (reading fluency) of 
the same children at the end of kindergarten (around 6 years of age) and at the end of the 1st grade of school (around 7 years of age) in three cohorts: US, Australia and Scandinavia (Norway and Sweden). At the end of kindergarten, genetic factors explained different amounts of variability in reading ability in the three populations: 0.84 in Australia; 0.68 in the US; and 0.33 in Scandinavia. The effects of shared environment were $0.09,0.25$ and 0.52 , respectively. However, one year later, by the end of the first grade, the differences in genetic and environmental effects between the three populations disappeared: genetic factors explained most $(79-83 \%)$ of the individual differences in reading in all three cohorts. The results were very similar for spelling.

The observed differences in pre-school heritability are likely to be explained by intensity of reading instruction in kindergarten and the home literacy environment. The Australian pre-school system has a strong emphasis on literacy instruction, with approximately twice as much instruction as in the US pre-school system. In Scandinavia, pre-school children rarely receive any literacy instruction in kindergarten; and parents of pre-school children engage in less shared book reading and letter-based activities with their children than parents from the US or Australia (Byrne et al., 2006). Although parents' own reading behaviours are similar across the countries, there is a tradition in Norway and Sweden not to subject children to formal or informal literacy instruction in the home during the pre-school years. In the absence of formal instruction, differences between families in the amount of literacy instruction are more likely to be reflected in children's literacy skills. However, these differences cannot be the only explanation for why shared environment explains most of the individual differences in literacy in Scandinavia. Although home literacy environment was positively correlated to early literacy skills, it explained only a small proportion of the individual differences in them. For example, shared book reading, the strongest predictor of print awareness, explained only 19\% of its variance (Byrne et al., 2006). Home environment is also not independent of genetic effects, as parents shape environments in line with their own genetic predispositions. Recent molecular genetics research has provided support for this, finding that DNA variants that contribute to differences in academic achievement also explain some of the variance in family SES (Selzam et al., 2016).

One explanation for lower heritability of pre-school literacy in Scandinavia and the US is that the effects of genes that affect early reading and spelling skills cannot be seen until children participate in intense literacy instruction. The results revealed that many of the same genetic effects that contribute to pre-school literacy continued to be important for school literacy. Some new genetic effects also emerged, suggesting that some genes are specific to further literacy development (Samuelson et al., 2007). These results are consistent with a large body of behavioural genetic findings, suggesting that heritability of pre-school early literacy indicators is on average lower (e.g. Kovas et al., 2005) than substantial heritability of literacy found throughout formal school education (e.g. Harlaar et al., 2005; Byrne et al., 2006; Kovas et al., 2013).

The robustly shown pattern of a steady increase in heritability of IQ throughout development (e.g. Haworth et al., 2010; Polderman et al., 2015; Tucker-Drob \& Bates, 2016) also supports the Gene-Gini interplay. Unlike numeracy and literacy, for which heritability remains stably high throughout the school system, heritability of IQ is moderate in primary school and continues to increase throughout education (Kovas 
et al., 2013). This may be because there is no formal instruction for intelligence, with more variance explained by environmental disparity. The gene by age trends for IQ parallel the gene by SES effects observed in the US (Tucker-Drob \& Bates, 2016). It is possible that both phenomena reflect a process of increased and accumulated effects of gene-environment interplay (Tucker-Drob \& Bates, 2016). Interestingly, similar gene by age and SES patterns have been reported for variability in BMI. One large study of Finnish twin pairs born in 1983-1987 showed that heritability of BMI increased and shared environment decreased from childhood to adolescence. However, parental education moderated the genetic and environmental influences: heritability of BMI was greater $(85-87 \%)$ for 11 - to 12-year-olds with high parental education than those with lower parental education (61-68\%) (Lajunen et al., 2012).

The stronger influence of shared environment in childhood is consistent with stronger effects of inequality on children (Phipps \& Lethbridge, 2008). For example, inequality-related residential segregation may particularly affect children. Children generally stay in their neighbourhoods, which differ significantly in the quality and quantity of crucial public amenities, such as schools, parks, libraries and recreation (Bischoff \& Reardon, 2014). In the US, children attending public schools spend an average of only $18 \%$ (1000 hours) of their waking hours per year in the school environment (Kirsch et al., 2016). Therefore, most of a child's development takes place outside the school environment - mainly in the neighbourhood. Moreover, when disparity in quality across schools is high, the influence of residential segregation by income extends to schools. For example, in the US, a child from a low-income family is two to four times as likely as a child from an affluent family to have classmates with low skills and with behaviour problems, in both elementary and high school (Duncan \& Murnane, 2016). In the PISA study, students attending socioeconomically advantaged schools outscored those in disadvantaged schools by more than 104 points in mathematics (OECD, 2013).

Overall, the pattern of age-related changes in heritability suggests that schools may buffer at least some of the environmental disparities. Greater equity, afforded by formal education, leads to less variance in children's achievement explained by environmental factors, and more variance explained by genetic factors.

\section{Conclusions}

The reviewed research suggests that equality/inequality can have profound effects on the heritability of educational outcomes in a population. Not all estimates in the reviewed literature are consistent. This is not surprising as many samples are underpowered and measures are not always precise. However, the overall pattern of results from recent large-scale studies and meta-analyses is consistent with the Gene-Gini hypothesis. The evidence points to three major conclusions regarding variability in educational outcomes:

(1) When inequality is high, genetic factors explain more variance among people of higher SES than among those of low SES. In populations where access to quality education is the privilege of the rich, differences in academic outcomes are largely due to socioeconomic disparities. 
(2) When environmental provisions are relatively equally accessible and uniform (e.g. high-quality unified compulsory education), genetic factors explain most of the differences among people. Therefore, the strength of heritability can be viewed as a measure of environmental equality in a population. The observed sex and cohort differences in the proportion of variance in educational attainment explained by genetic factors suggest that heritability may also be viewed as an estimate of social mobility: decrease in heritability and increase in shared environment may reflect a decrease in the opportunity for mobility (Tucker-Drob et al., 2013).

(3) After environmental disparities are reduced, much variability in educational outcomes remains. This variability is largely driven by genetic differences. Heritability can also be affected by 'benign inequality', such as differences across countries in when children start receiving formal instruction (e.g. in literacy): heritability of a trait (e.g. reading ability) increases when formal instruction begins.

Reducing the effects of environmental disparity on educational achievement is a challenge for every society. Another challenge is to address the implications of greater heritability at greater equality levels. One common misconception is that traits that show substantial heritability are not modifiable through environmental interventions. This is not correct. For example, heritability of human height is around $80 \%$, yet huge changes have occurred in the population's average height in recent generations - suggesting that genes influence complex outcomes through channels that are modifiable (Cesarini \& Visscher, 2017). Another common misconception is that high heritability of traits can be used to support eugenic agenda of manipulating populations' genetic pools to achieve greater outcomes for societies (see Afterword for discussion). As this review has shown, genetic effects can be enhanced or suppressed without any changes in the genetic pool of a population.

With genetic testing allowing for more precise predictions of outcomes, one worry is that education may adopt gene-based ability tracking/streaming. Ability streaming, practised in many educational systems, has (to some extent) always been implicitly based on genetic information, as children are allocated to streams on the basis of their previous achievement. However, the existing crude system of streaming does not benefit struggling students. In fact, research has shown that early tracking/streaming may decrease achievement of all students and also increase educational inequality, by leading to a greater reduction in achievement for low-achieving students than high-achieving students (Hanushek \& Wobmann, 2006). To the extent that the early achievement gap is associated with differences in family background, track placements may reflect these differences and lead to further disparities in education. Lower achievement tracks may also not provide challenging or motivational environments to activate genetic propensities. Indeed, tracking may be another factor that leads to a decrease in heritability for educational achievement.

Education of the future will have to do much more to address not just wealth disparities, but also genetic disparities. Children with propensities for learning difficulties will require special and enhanced professional support. Similarly, schools will need to adapt to the needs of gifted students, so that inadequate environments do not limit their genetic propensities. The use of educational technologies may enable all children to optimize their learning, including by studying at different times of the day (suitable for individual chronotype); and learning material in a different order and pace - supporting individual interest and ability trajectories. Teachers of the future may assume a role of 
multi-disciplinary experts who are able to direct and assist individual children's trajectories. These efforts will not eliminate the achievement gap, but would be likely to reduce variability, particularly by enabling greater performance for lower achieving learners. This narrowing of the achievement gap has already been demonstrated in populations that have managed to reduce environmental disparity. As demonstrated in these populations, the remaining variability is likely to still be substantially heritable. However, by reducing some of the negative effects of genes, personalized education will lead to better results for everyone.

In isolation, differences in wealth or equality across populations do not directly map onto the populations' average achievement rankings. A simple analysis was conducted plotting the ranks of twelve countries participating in PISA for three indices: PPP, Gini and performance on a standardized test of mathematical ability of 15-year-old students (OECD, 2016, 2017). The countries (presented in decreasing order for PISA results) were: China, Holland, Canada, Japan, Australia, Denmark, Germany, Sweden, UK, Norway, Russia and the US. There was no obvious relationship between population average PISA scores, PPP and Gini. For example, out of the twelve countries, China had the second worst PPP and the worst Gini, but scored the highest out of the twelve countries (and out of 34 OECD countries included in PISA 2012). The US had a good PPP, but high Gini, and scored the lowest of the twelve countries (and below average of the 34 countries). Norway had the best PPP and low (good) Gini, but about average performance on PISA. This suggests that many factors contribute to the average performance of a nation and these factors may differ between countries. As discussed in this review, Gene-Gini interplay may be one key factor that affects variance and average achievement of populations. Further research, with large cross-cultural datasets, should also test whether an interaction between PPP and Gini may explain more variance in educational achievement than each indicator alone.

The focus of this review is on outcomes for individuals within populations - an attempt to understand how environmental set-ups, including access to resources, suppress or enhance the genetic propensities of individuals. Understanding the dynamic ongoing processes of Gene-Gini interplay will help educational systems to evolve further, so that they are adapted to the individual needs of all students.

\section{Afterword (Gini and eugenics)}

Corrado Gini's significance to this paper was limited to that of a statistician who developed the Gini Coefficient. However, learning about his interest in eugenics added an unexpected twist to the title of this review and called for a few words on eugenics. For Corrado Gini, statistics was a methodological lens through which it was possible to observe populations, economies, social classes, wars and other large-scale phenomena (Prévost, 2016). The application of statistics to eugenics was his particular passion (Berlivet, 2016), culminating in his appointment in October 1935 as the inaugural president of the Latin International Federation of Eugenic Societies. This, together with his role in various academic and governmental offices before, during and after the fascist regime in Italy, makes Corrado Gini a controversial figure (Macuglia, 2014).

Eugenics originated from Francis Galton's theorizing and developed into a popular movement in the UK in the early $20^{\text {th }}$ century, spreading to many countries. 
The central purpose of the eugenic movement was described as improving a human population (stock) by controlled breeding to increase the occurrence of desirable heritable characteristics' (en.oxforddictionaries.com). Particularly in the AngloSaxon eugenic model, its purpose was formulated as: eliminating from subsequent generations beings 'inferior by heredity' (negative selection); and increasing the reproductivity of the 'best' (positive selection). This led to unethical practices in many countries, including forced sterilization of people deemed unfit and marriage prohibition, and encouraging particularly 'fit' individuals to reproduce (see Kevles, 1985 , for a review).

It is necessary to mention that Corrado Gini himself did not support this agenda for eugenics. According to him, societies were too ignorant of the mechanisms of genetic and environmental influences to exercise social control on populations (Gini, 1932). In fact, he recognized that attempts to reduce the genetic variability of a population may have catastrophic effects. In his view, the purpose of eugenics was to study successive generations, isolated populations and migrants - and how populations change over time. He believed that genetics and statistics provided the foundation of such study. In fact, his proposed programme and motto for eugenics in the immediate future was 'facts, facts, facts' (Gini, 1932). Altogether, Gini's theorizing can be viewed as accepting that environment and heredity interact in complex ways (Berlivet, 2016). It therefore seems more appropriate to describe his interest as interdisciplinary, including sociology, demography, anthropology, genetics and statistics - with an unfortunate focus on eugenics. It is also worth mentioning that historically, the term eugenics applied also to benign practices, such as avoidance of inbreeding, or prenatal care for mothers.

Eugenics cast a long shadow over genetic research, with many people rightly worrying about the potential unethical applications of genetic knowledge. Apart from the dangers of selective breeding and sterilization, neo-eugenic risks include forced prenatal 'people selection' and gene editing. These and other risks can only be avoided by appropriate safeguards against misuses of genetic information, such as increasing genetic literacy (Chapman et al., in press), enacting enforceable laws and providing equal access to justice (Selita, 2018).

Behavioural genetics is fundamentally different from any form of eugenics. Eugenics is concerned with factors through which societies rise and decline, and ways to maximize societies' potential. In contrast, the purpose of behavioural genetics (and of this review) is to gain insight into the complex processes driving the development of each individual. This includes understanding the influences that societies have on individuals, such as the effects of inequality on people's genetic potential.

Ethical Approval. The authors assert that all procedures contributing to this work comply with the ethical standards of the relevant national and institutional committees on human experimentation and with the Helsinki Declaration of 1975, as revised in 2008.

Conflicts of Interest. The authors have no conflicts of interest to declare.

Funding. This work was supported by the Tomsk State University Competitiveness Improvement Program (Grant 8.1.09.2017). 


\section{References}

Allianz (2016) Allianz Global Wealth Report 2016. URL: www.allianz.com/v_1474281539000/ media/economic_research/publications/specials/en/AGWR2016e.pdf (accessed 5th May 2017).

Alvaredo, F., Atkinson, A. B., Piketty, T. \& Saez, E. (2013) The top 1 percent in international and historical perspective. Journal of Economic Perspectives 27(3), 3-20.

Ansell, D. (2017) The Death Gap: How Inequality Kills. University of Chicago Press. ISBN: 9780226428291.

Asbury, K., Wachs, T. D. \& Plomin, R. (2005) Environmental moderators of genetic influence on verbal and nonverbal abilities in early childhood. Intelligence 33, 643-661.

Atkinson, A. B., Piketty, T. \& Saez, E. (2011) Top incomes in the long run of history. Journal of Economic Literature 49(1), 3-71.

Bates, T., Hansell, N. K., Martin, N. G. \& Wright, M. J. (2016) When does socioeconomic status (SES) moderate the heritability of IQ?: no evidence for $g$ x SES interaction for IQ in a representative sample of 1,176 Australian adolescent twin pairs. Intelligence 56, 10-15.

Berlivet, L. A. (2016) A laboratory for Latin eugenics: the Italian Committee for the Study of Population Problems and the international circulation of eugenic knowledge, 1920s-1940s. História, Ciências, Saúde - Manguinhos 23(1), 51-72.

Bick, J., Naumova, O., Hunter, S., Barbot, B., Lee, M., Luthar, S. S. \& Grigorenko, E. L. (2012) Childhood adversity and DNA methylation of genes involved in the hypothalamus-pituitaryadrenal axis and immune system: whole-genome and candidate-gene associations. Development and Psychopathology 24(4), 1417-1425.

Bischoff, K. \& Reardon, S. F. (2014) Residential segregation by income 1970-2009. In Logan, J. (ed.) Diversity and Disparities: America Enters a New Century. Russell Sage Foundation, New York.

Branigan, A. R., McCallum, K. J. \& Freese, J. (2013) Variation in the heritability of educational attainment: an international meta-analysis. Social Forces 92(1), 109-140.

Braveman, P. \& Gottlieb, L. (2014) The social determinants of health: it's time to consider the causes of the causes. Public Health Reports 129(1) (Supplement 2), 19-31.

Byrne, B., Olson, R. K., Samuelsson, S., Wadsworth, S., Corley, R., DeFries, J. C. \& Willcutt, E. (2006) Genetic and environmental influences on early literacy. Journal of Research in Reading 29(1), 33-49.

Carter, P. L. \& Reardon, S. F. (2014) Inequality Matters. William T. Grant Foundation URL: https://ed.stanford.edu/sites/default/files/inequalitymatters.pdf (accessed 31st May 2017).

Ceriani, L. \& Verme, P. (2012) The origins of the Gini index: extracts from Variabilità e Mutabilità (1912) by Corrado Gini. Journal of Economic Inequality, doi: 10.1007/s10888-0119188-x.

Cesarini, D. \& Visscher, P. M. (2017) Genetics and educational attainment. npj Science of Learning 2(4), doi:10.1038/s41539-017-0005-6.

Chapman, R., Likhanov, M., Selita, F., Zakharov, I., Smith-Woolley, E. \& Kovas, Y. (in press) Genetic Literacy and Attitudes Survey (iGLAS): International Population-Wide Assessment Instrument. Journal of Community Genetics.

Chartbook of Economic Inequality (2017) Inequality by Country. URL: www.chartbookof economicinequality.com/inequality-by-country (accessed 27th May 2017).

Chiang, T. L. (1999) Economic transition and changing relation between income inequality and mortality in Taiwan: regression analysis. British Medical Journal 319(7218), 1162-1165.

Cobham, A., Schlogl, L. \& Sumner, A. (2015) Inequality and the tails: the Palma Proposition and Ratio revisited. United Nations Department of Economics and Social Affairs. Working Paper No. 143, doi: ST/ESA/2015/DWP/143. www.un.org/esa/desa/papers/2015/wp143_2015.pdf. 
Colodro-Conde, L., Rijsdijk, F., Tornero-Gómez, M. J., Sánchez-Romera, J. F. \& Ordoñana, J. R. (2015) Equality in educational policy and the heritability of educational attainment. PLoS One 10(11), e0143796.

Corak, M. (2013) Income inequality, equality of opportunity and intergenerational mobility. Journal of Economic Perspectives 27(3), 79-102.

County Health Rankings and Roadmaps (2015) Key Findings Report 2015. URL: http://www.rwjf. org/content/dam/farm/reports/reports/2015/rwjf418649 (accessed 31st May 2017).

Coussons-Read, M., Okun, M. \& Nettles, C. (2007) Psychosocial stress increases inflammatory markers and alters cytokine production across pregnancy. Brain, Behavior, and Immunity 21(3), 343-350.

Crawford, R., Innes, D. \& O'Dea, C. (2016) Household wealth in Great Britain: distribution, composition and changes 2006-12. Fiscal Studies 37(1), 35-54.

Credit Suisse (2014) Global Wealth Databook 2014. URL: www.credit-suisse.com/us/en/about-us/ research/research-institute/global-wealth-report.html (accessed 31st May 2017).

Credit Suisse (2016) Global Wealth Databook 2016. URL: http://publications.creditsuisse.com/ tasks/render/file/index.cfm?fileid=AD6F2B43-B17B-345E-E20A1A254A3E24A5 (accessed 31st May 2017).

Davies, J. B. (2016) The Gini Coefficient and Personal Inequality Measurement. Department of Economics Research Report 2016-1. Department of Economics, University of Western Ontario, London, ON, Canada. URL: http://ir.lib.uwo.ca/economicsresrpt/812/ (accessed 30th May 2017).

De Maio, F. G. (2007) Income inequality measures. Journal of Epidemiology and Community Health 61(10), 849-852.

Duncan, G. \& Murnane, R. (eds) (2011) Whither Opportunity? Rising Inequality, Schools, and Children's Life Chances. Russell Sage Foundation, New York.

Duncan, G. J. \& Murnane, R. J. (2016) Rising inequality in family incomes and children's educational outcomes. Russell Sage Foundation Journal of the Social Sciences 2(2), 142-158.

Ford, E., Loucks, E. \& Berkman, L. (2006) Social integration and concentrations of c-reactive protein among US adults. Annals of Epidemiology 16(2), 78-84.

Galbraith, J. K., Krytynskaia, L. \& Wang, Q. (2004) The experience of rising inequality in Russia and China during the rransition. European Journal of Comparative Economics 1(1), 87-106.

Gastwirth, J. L. (2016) Is the Gini Index of Inequality Overly Sensitive to Changes in the Middle of the Income Distribution? SSRN. URL: https://ssrn.com/abstract=2884308 (accessed 31st May 2017).

Gianaros, P., Marsland, A., Sheu, L., Erickson, K. \& Verstynen, T. (2012) Inflammatory pathways link socioeconomic inequalities to white matter architecture. Cerebral Cortex 23(9), 2058-2071.

Gini, C. (1932) Address at the Third International Congress of Eugenics. American Museum of Natural History, New York City. URL: http://www-history.mcs.st-and.ac.uk/Extras/Gini_ Eugenics.html

Grigorenko, E. L., LaBuda, , Michele, C. \& Carter, A. S. (1992) Similarity in general cognitive ability, creativity, and cognitive style in a sample of adolescent Russian twins. Acta Geneticae Medicae et Gemellologiae: Twin Research 41(1), 65-72.

Hales, S., Howden-Chapman, P., Salmond, C., Woodward, A. \& Mackenbach, J. (1999) National infant mortality rates in relation to gross national product and distribution of income. Lancet 354(9195), 2047.

Hanscombe, K. B., Trzaskowski, M., Haworth, C. M., Davis, O. S., Dale, P. S. \& Plomin, R. (2012) Socioeconomic status (SES) and children's intelligence (IQ): in a UK-representative sample SES moderates the environmental, not genetic, effect on IQ. PLoS One 7(2), e30320. 
Hanushek, E. A. \& Wobmann, L. (2006) Does educational tracking affect performance and inequality? Differences-in-differences evidence across countries. Economic Journal 116, C63-C76.

Harlaar, N., Spinath., F. M., Dale, P. S. \& Plomin, R. (2005) Genetic influences on early word recognition abilities and disabilities: a study of 7-year-old twins. Journal of Child Psychology \& Psychiatry 46(4), 373-384.

Haworth, C. M. A., Wright, M. J., Luciano, M., Martin, N. G., de Geus, E. J. C., van Beijsterveldt, C. E. M. et al. (2010) The heritability of general cognitive ability increases linearly from childhood to young adulthood. Molecular Psychiatry 15, 1112-1120.

Hayiou-Thomas, M. E. (2008) Genetic and environmental influences on early speech, language and literacy development. Journal of Communication Disorders 41(5), doi: 10.1016/j. jcomdis.2008.03.002.

Henry, J., Boivin, M. \& Brendgen, M. (2016) Gene-environment correlations in the context of parenting and peer relationships. In Kovas, Y. et al. (eds) Behavioural Genetics for Education. Palgrave Macmillan, pp. 42-59.

Johnson, S. L., Wibbels, E. \& Wilkinson, R. (2015) Economic inequality is related to cross-national prevalence of psychotic symptoms. Social Psychiatry and Psychiatric Epidemiology 50(12), 1799-1807.

Jorde, L. B. \& Wooding, S. P. (2004) Genetic variation, classification and 'race'. Nature Genetics 36, S28-S33.

Kevles, D. J. (1985) In the Name of Eugenics: Genetics and the Uses of Human Heredity. University of California Press.

Kalil, A., Ziol-Guest, K. M., Ryan, R. M. \& Markowitz, A. J. (2016) Changes in income-based gaps in parent activities with young children from 1988 to 2012. AERA Open, doi: $10.1177 /$ 2332858416653732. URL: http://journals.sagepub.com/doi/full/10.1177/2332858416653732

Kaplan, G. A., Salonen, J. T., Cohen, R. D., Brand, R. J., Syme, S. L. \& Puska, P. (1988) Social connections and mortality from all causes and from cardiovascular disease: prospective evidence from eastern Finland. American Journal of Epidemiology 128(2), 370-380.

Kawachi, I. \& Kennedy, B. P. (1997) The relationship of income inequality to mortality: does the choice of indicator matter? Social Science \& Medicine 45(7), 1121-1127.

Kerry, B., Pickett, K. E. \& Wilkinson, R. (2010) The Spirit Level: Why Greater Equality makes Societies Stronger. Child Poverty Insights. URL: www.unicef.org/socialpolicy/index_70086.html (accessed 31st May 2017).

Kiecolt-Glaser, J., Gouin, J. \& Hantsoo, L. (2010) Close relationships, inflammation, and health. Neuroscience \& Biobehavioral Reviews 35(1), 33-38.

Kirsch, I., Braun, H., Lennon, M. L. \& Sands, A. (2016) Choosing Our Future: A Story of Opportunity in America. Educational Testing Service, URL: www.ets.org/research/report/ opportunity (accessed 31st May 2017).

Kornrich, S. \& Furstenberg, F. (2013) Investing in children: changes in parental spending on children, 1972-2007. Demography 50(1), 1-23.

Kovas, Y., Garon-Carrier, G., Boivin, M., Petrill, S. A., Malykh, S. B., Spinath, F. et al. (2015) Why children differ in motivation to learn: insights from over 13,000 twins from 6 countries. Personality and Individual Differences 80, 51-63.

Kovas, Y., Hayiou-Thomas, M. E., Oliver, B., Dale, P. S., Bishop, D. V. M. \& Plomin, R. (2005) Genetic influences in different aspects of language development: the etiology of language skills in 4.5 year-old twins. Child Development 76(3), 632-651.

Kovas, Y., Henry, J., Feklicheva, I., Soldatova, E. \& Malykh, S. (2016) Early environment and development: epigenetic mechanisms. In Malykh, S. B. et al. (eds) (2016) Behavioural Genomics: Child Development and Education. Publishing House of Tomsk State University, Tomsk. Chapter 10, pp. 226-237. ISBN: 978-5-94621-585-5. 
Kovas, Y. \& Malykh, S. (2016) Behavioural genomics and education. In Malykh, S. B. et al. (eds) Behavioural Genomics: Child Development and Education. Publishing House of Tomsk State University, Tomsk. pp. 382-391. ISBN: 978-5-94621-585-5.

Kovas, Y., Voronin, I., Kaydalov, A., Malykh, S. B., Dale, P. S. \& Plomin, R. (2013) Literacy and numeracy are more heritable than intelligence in primary school. Psychological Science 24(10), 2048-2056.

Krapohl, E., Rimfeld, K., Nicholas, G., Shakeshaft, N., Trzaskowski, M., McMillan, A. et al. (2014) The high heritability of educational achievement reflects many genetically influenced traits, not just intelligence. PNAS. URL: www.pnas.org/cgi/doi/10.1073/pnas.1408777111

Lajunen, H.-R., Kaprio, J., Rose, R. J., Pulkkinen, L. \& Silventoinen, K. (2012) Genetic and environmental influences on BMI from late childhood to adolescence are modified by parental education. Obesity 20(3), 583-589.

Loucks, E., Berkman, L., Gruenewald, T. \& Seeman, T. (2006) Relation of social integration to inflammatory marker concentrations in men and women 70 to 79 years. American Journal of Cardiology 97(7), 1010-1016.

Macuglia, D. (2014) Corrado Gini and the scientific basis of fascist racism. Medicina Nei Secoli 26(3), 821-855.

Magnuson, K. \& Waldfogel, J. (2008) Steady Gains and Stalled Progress: Inequality and the BlackWhite Test Score Gap. Russell Sage Foundation, New York. URL: https://www.russellsage.org/ publications/steady-gains-and-stalled-progress-0

Malykh, S. B., Iskoldsky, N. V. \& Gindina, E. D. (2005) Genetic analysis of IQ in young adulthood: a Russian twin study. Personality and Individual Differences 38, 1475-1485.

Malykh, S., Voronin, I., Ismatullina, V., Zaharov, I., Belova, A. \& Lobaskova, M. (2016) Genetic and environmental sources of individual differences in non-verbal intelligence in Russian adolescents. SHS Web of Conferences 29, doi: 10.1051/ 02026.

Marmot, M. G., Rose, G., Shipley, M. J. \& Hamilton, P. J. (1978) Employment grade and coronary heart disease in British civil servants. Journal of Epidemiology and Community Health 32(4), 244-249.

Marmot, M. G., Shipley, M. J. \& Rose, G. (1984) Inequalities in death-specific explanations of a general pattern? Lancet 1(8384), 1003-1006.

Meaney, M. J. (2010) Epigenetics and the biological definition of gene-environment interactions. Child Development 81, 41-79.

Miller, G. \& Chen, E. (2007) Unfavorable socioeconomic conditions in early life presage expression of proinflammatory phenotype in adolescence. Psychosomatic Medicine 69(5), 402-409.

OECD (2013) Excellence through Equity: Giving Every Student the Chance to Succeed. Volume II. URL: https://www.oecd.org/pisa/keyfindings/pisa-2012-results-volume-II.pdf

OECD (2014) PISA 2012 Results in Focus: What 15-year-olds now and what they can do with what they know. URL: https://www.oecd.org/pisa/keyfindings/pisa-2012-results-overview.pdf (accessed 1st September 2017).

OECD (2016) PISA 2015 Results in Focus: Excellence and equity in education. URL: https://www. oecd.org/pisa/pisa-2015-results-in-focus.pdf (accessed 31st May 2017).

OECD (2017) OECD Income Distribution Database (IDD): Gini, Poverty, Income, Methods and Concepts. URL: http://www.oecd.org/social/income-distribution-database.htm (accessed 24th May 2017).

OECD (2017) Poverty Rate (Indicator), doi: 10.1787/0fe1315d-en URL: https://data.oecd.org/ inequality/poverty-rate.htm (accessed 1st September 2017).

Okbay, A., Beauchamp, J. P., Fontana, M. A., Lee, J. J., Pers, T. H., Rietveld, C. A. et al. (2016) Genome-wide association study identifies 74 loci associated with educational attainment. Nature 533, 539-542. 
Oxfam (2016) An Economy for the 1\%. Oxfam Briefing Paper. URL: org/en/research/economy-1 (accessed 27th May 2017).

Oxfam (2017a) An Economy for the 99\%. Oxfam Briefing Paper. URL: oxfam.org/en/research/ economy-99 (accessed 27th May 2017).

Oxfam (2017b) Just 8 men own same wealth as half the world. Press Release. URL: oxfam.org/en/ pressroom/pressreleases/2017-01-16/just-8-men-own-same-wealth-half-world (accessed 31st May 2017).

Phipps, S. \& Lethbridge, L. (2008) Income and the Outcomes of Children. Analytical Studies Branch Research Paper Series No. 281. Statistics Canada. URL: http://www.statcan.gc.ca/pub/ 11-015-x/earning-gain/4070043-eng.htm

Pickett, K. \& Wilkinson, R. G. (2007) Child wellbeing and income inequality in rich societies: ecological cross sectional study. British Medical Journal 335, 1080.

Pickett, K. E. \& Wilkinson, R. G. (2015) Population health: behavioral and social science insights. Income inequality and health: a causal review. Social Science \& Medicine 128, 316-326.

Piketty, T. \& Saez, E. (2003) Income inequality in the United States, 1913-1998. Quarterly Journal of Economics 118(1), 1-41.

Piketty, T. \& Saez, E. (2014) Inequality in the long run. Science 344(6186).

Pinto, R., Ashworth, M. \& Jones, R. (2008) Schizophrenia in black Caribbeans living in the UK: an exploration of underlying causes of the high incidence rate. British Journal of General Practice 58(551), 429-434.

Plomin, R. \& Bergeman, C. S. (1991) The nature of nurture: genetic influence on "environmental" measures. Behavioral and Brain Sciences 14, 373-427.

Plomin, R. \& Deary, I. J. (2015) Genetics and intelligence differences: five special findings. Molecular Psychiatry 20(1), 98-108.

Plomin, R., DeFries, J. C., Knopik, V. S. \& Neiderhiser, J. M. (2016) Top 10 replicated findings from behavioral genetics. Perspectives on Psychological Science 11(1), 3-23.

Plomin, R., DeFries, J. C. \& Loehlin, J. C. (1977) Genotype-environment interaction arid correlation in the analysis of human behavior. Psychological Bulletin 84(2), 309-322.

Polderman, T. J. C., Benyamin, B., de Leeuw, C. A., Sullivan, P. F., van Bochoven, A., Visscher, P. M. \& Posthuma, D. (2015) Meta-analysis of the heritability of human traits based on fifty years of twin studies. Nature Genetics 47(7), 702-709.

Prévost, J. G. (2016) Statistics, expertise and politics: Corrado Gini and the course of Italian history. METRON 74, 145-165.

Reardon, F. (2013) The widening income achievement gap. Educational Leadership 70(8), 10-16.

Reardon, S. F. (2011) The widening academic achievement gap between the rich and the poor: new evidence and possible explanations. Community Investments 24(2), 19-39.

Rietveld, C. A., Medland, S. E., Derringer, J., Yang, J., Esko, T., Martin, N. W. et al. (2013) GWAS of 126,559 individuals identifies genetic variants associated with educational attainment. Science 340(6139), 1467-1471.

Rimfeld, K., Ayorech, Z., Dale, P. S., Kovas, Y. \& Plomin, R. (2016) Genetics affects choice of academic subjects as well as achievement. Scientific Reports 6, 26373.

Rowlingson, K. (2011) Does income inequality cause health and social problems? Report. Joseph Rowntree Foundation. URL: https://www.jrf.org.uk/sites/default/files/jrf/migrated/files/inequalityincome-social-problems-full.pdf (accessed 25th May 2017).

Ryan, B. A. \& Adams, G. R. (1998) Family relationships and children's school achievement: data from the national longitudinal survey of children and youth. Human Resources Development Canada. URL: http://citeseerx.ist.psu.edu/viewdoc/download?doi=10.1.1.559.6350\&rep=rep1\&type=pdf

Saez, E. (2015) U.S. income inequality persists amid overall growth in 2014. Washington Centre for Equitable Growth. URL: http://equitablegrowth.org/research-analysis/u-s-income-inequalitypersists-amid-overall-growth-2014/ (accessed 24th May 2017). 
Saez, E. \& Zucman, G. (2014) Wealth inequality in the United States since 1913: evidence from capitalized income tax data. NBER Working Paper No. 20625. URL: http://www.nber.org/ papers/w20625

Samuelsson, S., Byrne, B., Olson, R. K., Hulslander, J., Wadsworth, S., Corley, R., Willcutt, E. G. \& DeFries, J. C. (2008) Response to early literacy instruction in the United States, Australia, and Scandinavia: a behavioral-genetic analysis. Learning \& Individual Differences 18(3), 289-295.

Schwabe, I., Boomsma, D. I. \& van den Berg, S. M. (2017) Increased environmental sensitivity in high mathematics performance. Learning and Individual Differences 54, 196-201.

Schwartz, J. A. (2015) Socioeconomic status as a moderator of the genetic and shared environmental influence on verbal IQ: a multilevel behavioral genetic approach. Intelligence 52, $80-89$.

Selita, F. (2018) Unrepresented Litigants in Modern Courts - Ordeal by Combat. Legal Issues Journal 6(1).

Selzam, S., Krapohl, E., von Stumm, S., O'Reilly, P. F., Rimfeld, K., Kovas, Y. et al. (2016) Predicting educational achievement from DNA. Molecular Psychiatry 22, 267-272.

Shakeshaft, N. G., Trzaskowski, M., McMillan, A., Rimfeld, K., Krapohl, E., Haworth, C. M. et al. (2013) Strong genetic influence on a UK nationwide test of educational achievement at the end of compulsory education at age 16. PLoS One 8(12), e80341.

Silventoinen, K., Sarlio-Lahteenkorva, S., Koskenvuo, M., Lahelma, E. \& Kaprio, J. (2004) Effect of environmental and genetic factors on education-associated disparities in weight and weight gain: a study of Finnish adult twins. American Society for Clinical Nutrition 80, 815-822.

Singer, B. H. \& Ryff, C. D. (eds) (2001) New Horizons in Health: An Integrative Approach. National Research Council (US). National Academies Press, Washington, DC.

Social Policy Research Centre (2016) Poverty in Australia 2016. Australian Council of Social Service. URL: http://www.acoss.org.au/wp-content/uploads/2016/10/Poverty-in-Australia-2016. pdf (accessed 6th June 2017).

Sommeiller, M. \& Price, M. (2015) The Increasingly Unequal States of America: Income Inequality by State, 1917 to 2012. EARN - Economic Analysis and Research Network. URL: http://www. epi.org/publication/income-inequality-by-state-1917-to-2012/

Telenti, A., Pierce, L. C. T., Biggs, W. H., Dilulio, J., Wong, E. H. M., Fabani, M. M. et al. (2016) Deep sequencing of 10,000 human genomes. PNAS 113(42), 11901-11906.

Tucker-Drob, E. M. \& Bates, T.C. (2016) Large cross-national differences in gene $\times$ socioeconomic status interaction on intelligence. Psychological Science 27(2), 138-149.

Tucker-Drob, E. M., Briley, A. D. \& Harden, K. P. (2013) Genetic and environmental influences on cognition across development and context. Current Directions in Psychological Science 22(5), 349-355.

Tucker-Drob, E. M. \& Harden, K. P. (2012) Early childhood cognitive development and parental cognitive stimulation: evidence for reciprocal gene-environment transactions. Developmental Science 15(2), 250-259.

Tucker-Drob, E. M., Rhemtulla, M., Harden, K. P., Turkheimer, E. \& Fask, D. (2011) Emergence of a gene $\times$ socioeconomic status interaction on infant mental ability between 10 months and 2 years. Psychological Science 22, 125-133.

UNDP (2013) UNDP Income Report 2013. URL: http://hdr.undp.org/en/content/income-ginicoefficient (accessed 31st May 2017).

UNDP (2014) UNDP Income Report 2014. URL: http://hdr.undp.org/en/content/income-ginicoefficient (accessed 31st May 2017).

UNDP (2016) UNDP PPP Report 2016. URL: http://hdr.undp.org/en/indicators/136706\# (accessed 24 ${ }^{\text {th }}$ May 2017). 
UNICEF (2016) Fairness for Children: A League Table of Inequality in Child Well-Being in Rich Countries. UNICEF Innocenti Report, Report Card 13. UNICEF Office of Research Innocenti. URL: www.unicef-irc.org/publications/pdf/RC13_eng.pdf

Voronin, I., Nijenhuis, J. T. \& Malykh, S. (2016) The correlation between $g$ loadings and heritability in Russia. Journal of Biosocial Science 48, 833-843.

Wilkinson, R. G. (1996) Unhealthy Societies: The Afflictions of Inequality. Routledge, London, New York.

Wilkinson, R. \& Marmot, M. (eds) (2003) Social Determinants for Health: The Solid Facts. 2nd Edition. World Health Organization. URL: http://www.euro.who.int/en/publications/abstracts/ social-determinants-of-health.-the-solid-facts

Wilkinson, R. G. \& Pickett, K. E. (2006) Income inequality and health: a review and explanation of the evidence. Social Science \& Medicine 62, 1768-1784.

Wilkinson, R. G. \& Pickett, K. E. (2009) The Spirit Level: Why Greater Equality Makes Societies Stronger. Bloomsbury Publishing, New York, London, New Delhi, Sidney.

Wilkinson, R. G. \& Pickett, K. E. (2011) Greater equality: the hidden key to better health and higher scores. American Educator 35(1), 5-9.

Witherspoon, D. J., Wooding, S., Rogers, A. R., Marchani, E. E., Watkins, W. S., Batzer, M. A. \& Jorde, L. B. (2007) Genetic similarities within and between human populations. Genetics 176(1), 351-359.

World Bank (2015) The World Bank Infant Mortality Report (per 1,000 live births) URL: http:// data.worldbank.org/indicator/SP.DYN.IMRT.IN (accessed 24th May 2017).

World Bank (2017a) The World Bank GINI Report. URL: http://data.worldbank.org/indicator/SI. POV.GINI (accessed 27th May 2017).

World Bank (2017b) World Bank PPP Data. URL: http://data.worldbank.org/indicator/NY.GDP. PCAP.PP.CD (accessed 27th May 2017).

World Bank Institute (2005) Introduction to Poverty Analysis, pp. 95-105. URL: http:// siteresources.worldbank.org/PGLP/Resources/PovertyManual.pdf (accessed 31 May 2017).

World Economic Forum (2012) Global Risks 2012. Seventh Edition. Insight Report. URL: www3. weforum.org/docs/WEF_GlobalRisks_Report_2012.pdf (accessed 31st May 2017). 